Efficient Vol 1 (3) (2018): 214-223 DOI: https://doi.org/10.15294/efficient.vii3.27875
$\begin{gathered}\text { Indonesian Journal of Development Economics } \\ \text { https://journal.unnes.ac.id/sju/index.php/efficient }\end{gathered}$
ST

\title{
Analisis Pajak Daerah Dan Retribusi Daerah Provinsi Jawa Tengah
}

\author{
Adi Sulistiyanto
}

\author{
Jurusan Ekonomi Pembangunan,Fakultas Ekonomi, Universitas Negeri Semarang
}

Permalink/DOI: https://doi.org/10.15294/efficient.vii3.27875

Received: April 2018; Accepted: July 2018 ; Published: October 2018

\begin{abstract}
This study aims to determine the level of achievement of local taxes, retibusi area in terms of effectiveness, efficiency, and contribution. The data used in this research is secondary data in the form of data times series with the time period of $2010-2014$ are sourced from BPS Central Java Province, and journals and literature related to the research. The analytical method used is descriptive analysis conducted by collecting, clarifying, analyze and interpret the data obtained, by identifying the effectiveness of taxes and levies, identify efficiency taxes and levies as well as calculating the contribution daearah taxes and levies. These results indicate that the development of local tax revenue in Central Java province during the period $2010-2014$ has increased at an average of $14.42 \%$ per year, efektifias levies during the period 2010 to 2014 in table 5 the average level of effectiveness of $12.60 \%$ Based on the criteria of efficiency are used, indicating that DPPAD Central Java province has been conducting with a very efficient management, it means that the benefits gained outweigh the amount of expenses incurred during the period of 5 years, an average efficiency rate of local tax revenue amounting to $0.076 \%$, the average contribution of local taxes to PAD for a period of 5 years down the price range - average of $4.42 \%$, and the average contribution levies to PAD for a period of 5 years amounted to $0.0699 \%$. Based on these findings, suggestions can be submitted are necessary to improve oversight, supervision, and evaluation of the collection of local taxes and levies to increase local tax revenues that contribute to $P A D$.
\end{abstract}

Keywords: Local Taxes, Retribution, and on Outonomy Regional Resources Income (PAD)

\begin{abstract}
Abstrak
Penelitian ini bertujuan untuk mengetahui tingkat pencapaian pajak daerah, retibusi daerah dalam hal efektivitas, efisiensi, dan kontribusi. Data yang digunakan dalam penelitian ini adalah data sekunder berupa deret waktu data dengan periode waktu 2010 - 2014 yang bersumber dari BPS Provinsi Jawa Tengah, dan jurnal dan literatur yang terkait dengan penelitian. Metode analisis yang digunakan adalah analisis deskriptif yang dilakukan dengan mengumpulkan, memperjelas, menganalisa dan menginterpretasi data yang diperoleh, dengan mengidentifikasi efektivitas pajak dan retribusi, mengidentifikasi efisiensi pajak dan retribusi serta menghitung kontribusi pajak daearah dan retribusi. Hasil ini menunjukkan bahwa perkembangan penerimaan pajak daerah di Provinsi Jawa Tengah selama periode 2010 - 2014 mengalami peningkatan rata-rata $14,42 \%$ per tahun, retribusi efektifas selama periode 2010 hingga 2014 pada tabel 5 rata-rata tingkat efektivitas 12,60\% Berdasarkan kriteria efisiensi yang digunakan, menunjukkan bahwa DPPAD Provinsi Jawa Tengah telah melakukan dengan manajemen yang sangat efisien, itu berarti bahwa manfaat yang diperoleh lebih besar daripada jumlah biaya yang dikeluarkan selama periode 5 tahun, tingkat efisiensi rata-rata pajak daerah Pendapatan sebesar o,o76\%, kontribusi rata-rata pajak daerah ke PAD untuk jangka waktu 5 tahun ke bawah kisaran harga - rata-rata $4,42 \%$, dan rata-rata kontribusi retribusi ke PAD untuk jangka waktu 5 tahun sebesar o,0699\%. Berdasarkan temuan ini, saran yang dapat diajukan diperlukan untuk meningkatkan pengawasan, pengawasan, dan evaluasi pengumpulan pajak dan pungutan lokal untuk meningkatkan pendapatan pajak daerah yang berkontribusi pada PAD.
\end{abstract}

\section{Kata Kunci: Pajak Daerah, Retribusi, dan Penghasilan Sumber Daya Daerah di Luar Daerah (PAD)}

How to Cite: Sulistiyanto, A. (2018). Analisis Pajak Daerah Dan Retribusi Daerah Provinsi Jawa Tengah. EFFICIENT Indonesian Journal of Development Economics, 1(3), 214-223. https://doi.org/10.15294/efficient.vii3.27875

(C) 2018 Semarang State University. All rights reserved

\footnotetext{
凶 Alamat Korespondensi :

Alamat: Gedung L2 Lantai 2 FE Unnes

Kampus Sekaran, Gunungpati, Semarang, 50229

E-mail : efficientjournal@gmail.com
}

ISSN 


\section{PENDAHULUAN}

Menurut Kurniawan (2006), disahkannya UU No. 22 tahun 1999 tentang Pemerintah Daerah dan UU No. 25 tahun 1999 tentang Perimbangan Keuangan Pusat dan Daerah merupakan langkah besar yang ditunggutunggu oleh daerah. Lahirnya undang-undang ini diharapkan dapat menjadi suatu landasan percepatan dan pemerataan pertumbuhan ekonomi di daerah-daerah, yang selama ini dirasakan adanya ketimpangan-ketimpangan dalam pembangunan antara pusat dan daerah. Undang-undang tersebut selanjutnya disempurnakan dengan dikeluarkannya UU No. 32 tahun 2004 tentang Pemerintah Daerah dan UU No. 33 tahun 2004 tentang Perimbangan Keuangan Antara Pemerintah Pusat dan Pemerintah Daerah.

Menurut Khusaini (2006), sesuai dengan UU No. 32 dan 33 tahun 2004, perimbangan keuangan pusat dan daerah dalam rangka pelaksanaan desentralisasi fiskal mengandung pengertian bahwa kepada daerah diberikan kewenangan untuk memanfaatkan sumber keuangan sendiri didukung dengan perimbangan keuangan antara pusat dan daerah. Penyerahan berbagai kewenangan ini harus disertai dengan penyerahan dan pengalihan pembiayaan. Sumber pembiayaan yang paling penting adalah sumber pembiayaan yang dikenal dengan Pendapatan Asli Daerah (PAD), di mana salah satu komponen utamanya adalah penerimaan yang berasal dari komponen pajak daerah.

Terwujudnya pelaksanaan otonomi daerah, terjadi melalui proses penyerahaan sejumlah kekuasaan/kewenangan dari pemerintahan pusat ke pemerintah daerah dimana implementasi kebijakan desentralisasi memerlukan banyak faktor pendukung. Salah satu faktor pendukung yang signifikan menentukan keberhasilan pelaksanaan otonomi daerah adalah kemampuan daerah untuk membiayai pelaksanaan kekuasaan/kewenangan yang dimilikinya, disamping faktor-faktor lain seperti kemampuan personalia di daerah dan kelembagaan pemerintah daerah.

Efektivitas adalah keberhasilan atau kegagalan dari organisasi dalam mencapai tujuannya. Efektivitas menurut Hidayat (1986) yaitu suatu ukuran yang menyatakan seberapa jauh target (kuantitas, kualitas, dan waktu) yang telah tercapai. Dimana makin besar presentase target yang dicapai, makin tinggi efektivitasnya. Efektivitas pajak daerah adalah nilai yang dihitung berdasarkan prosentase perbandingan realisasi penerimaan pajak dengan target penerimaan pajak.

Sedangkan efisien menurut Halim (2004) merupakan pengukur besarnya biaya pemungutan yang digunakan terhadap realisasi penerimaan pajak daerah dan retribusi daerah itu sendiri. Pengukuran efektivitas dan efisiensi pajak daerah dan retribusi daerah sangat penting dilakukan guna melihat apakah ada peningkatan pengelolaan pajak daerah dan retribusi daerah. Pajak daerah dan retribusi daerah merupakan hal yang menarik untuk diteliti karena pajak daerah dan retribusi daerah merupakan salah satu sumber pendapatan daerah yang penting guna membiayai penyelenggaraan daerah dan pembangunan daerah untuk menetapkan Otonomi Daerah.

Oleh karena itu perlu dianalisis efektivitas dan efisiensi penerimaan pajak daerah dan retribusi daerah di Jawa Tengah, kemudian seberapa besar kontribusinya terhadap PAD Provinsi Jawa Tengah itu 
sendiri. Berdasarkan latar belakang masalah yang telah diuraikan diatas, maka peneliti tertarik untuk mengangkat kedalam penelitian yang berjudul "Analisis Efektivitas, Efisiensi, dan Kontribusi Pajak Daerah dan Retribusi Daerah Terhadap PAD Provinsi Jawa Tengah Tahun 2010-2014.

\section{METODE PENELITIAN}

Penelitian ini merupakan penelitian dokumenter dengan menggunakan sumber data sekunder berupa Realisasi Pendapatan Daerah Provinsi Jawa Tengah periode 20102014. Data yang digunakan dalam penelitian ini adalah data sekunder, data sekunder ini digunakan oleh peneliti untuk di proses lebih lanjut. Sugiyono (1997) menyatakan, bahwa variable di dalam penelitian merupakan suatu atribut dari sekelompok objek yang diteliti serta yang mempunyai variasi antara satu dengan yang lain dalam kelompok tersebut (Umar, 2008:47-48).

\section{Definisi Operasional}

Definisi operasional variabel penelitian ini sebagai berikut :

Target pajak daerah merupakan rencana anggaran yang ditetapkan dengan melihat data tahun sebelumnya. Target pajak daerah diperoleh dari Laporan Realisasi Pendapatan Daerah Provinsi Jawa Tengah periode 2010 2014. Realisasi pajak daerah merupakan hasil akhir pencapaian dari target pajak daerah yang telah ditentukan pada tahun bersangkutan. Realisasi pajak daerah diperoleh dari Laporan Realisasi Pendapatan Daerah Provinsi Jawa Tengah periode 2010-2014.

Biaya pemungutan penerimaan pajak daerah merupakan seluruh biaya yang dikeluarkan untuk memungut PAD, termasuk biaya langsung maupun tidak langsung dalam satuan rupiah pertahun. Biaya pemungutan pajak daerah diperoleh dari Dokumen Pelaksanaan Anggaran Satuan Kerja Perangkat Daerah Kegiatan Pengendalian Pajak Daerah/Intensifikasi, Ekstensifikasi, Sertifikasi Provinsi Jawa Tengah periode 20102014.

Untuk mengetahui tingkat efisiensi penerimaan pajak daerah menggunakan rumus sebagai berikut :

$$
\begin{aligned}
& \frac{\text { Biaya Pajak Daerah }}{\text { Realisasi Penerimaan Pajak daerah }} \times 100 \% \text {........(1) } \\
& \text { Adapun rumus yang digunakan untuk } \\
& \text { menghitung efisiensi retribusi daerah adalah } \\
& \text { sebagai berikut : } \\
& \frac{\text { Biaya Pemungutan Retribusi Daerah }}{\text { Realisasi Penerimaan Retribusi daerah }} \times 100 \% \ldots(2)
\end{aligned}
$$

Sedangkan untuk mengetahui tentang tingkat efektifitas pajak daerah, maka perlu mengetahui perkembangan pajak daerah pada masing-masing sektor setiap tahunnya. Adapun rumus yang digunakan untuk menghitung efektivitas pajak daerah adalah sebagai berikut:

$\frac{\text { Realisasi Penerimaan Pajak Daerah }}{\text { Target Penerimaan Pajak Daerah }} \times 100 \%$

Selanjutnya rumus yang digunakan dalam menghitung efektivitas retribusi daerah adalah sebagai berikut: 
$\frac{\text { Realisasi Penerimaan Retribusi Daerah }}{\text { Target Penerimaan Retribusi Daerah }} \times 100 \% \ldots .(4)$

Untuk mengetahui kontribusi penerimaan pajak daerah terhadap PAD menggunakan rumus sebagai berikut :

$\underline{\Sigma \text { Realisasi Penerimaan Pajak Daerah }}$ $\Sigma$ Realisasi Penerimaan $P A D$ $x 100 \%$

Sedangkan kontribusi retribusi daerah terhadap PAD dihitung melalui rumus sebagai berikut :

$\Sigma$ Realisasi Penerimaan Retribusi Daerah $\Sigma$ Realisasi Penerimaan $P A D$ $x 100 \% \ldots$

Penelitian ini menggunakan analisis deskriptif yang dilakukan dengan cara mengumpulkan, mengklarifikasi, menganalisis dan menginterpretasikan data yang diperoleh. Statistik deskriptif digunakan untuk memberikan informasi mengenai karakteristik variabel penelitian yang ada.

Langkah-langkah yang dilakukan yaitu :

(1) Mengidentifikasi perkembangan tingkat efisiensi pajak daerah periode tahun 2010-2014.

(2) Mengidentifikasi perkembangan tingkat efisiensi retribusi daerah tahun 2010-2014. Hasil pengukuran menggunakan kategori nilai sebagai berikut :

Sangat efisien (o-20\%)

Efisien $(21 \%-40 \%)$

Cukup efisien $(41 \%-60 \%)$

Tidak efisen $(61 \%-80 \%)$
Sangat tidak efisien (> 80\%)

Sumber : Sidik (dikutip oleh Enggar, Sri Rahayu dan Wahyudi, 2011)

(3) Menghitung perkembangan dan tingkat efektivitas pajak daerah pada periode tahun 2010-2014.

(4) Menghitung perkembangan dan tingkat efektivitas retribusi daerah pada periode tahun 2010-2014. Hasil pengukuran menggunakan kategori nilai sebagai berikut :

(1) Sangat tidak efektif (o - 40\%)

(2) Tidak efektif $(40 \%-60 \%)$

(3) Cukup efektif $(60 \%-80 \%)$

4) Efektif (8o\% - 100\%)

(5) Sangat efektif (> 100\%)

Sumber : Sidik (dikutip oleh Enggar, Sri Rahayu dan Wahyudi, 2011)

(5) Mengidentifikasi biaya pemungutan pajak daerah pada periode tahun 2010-2014.

(6) Menghitung besar kontribusi pajak daerah dan retribusi daerah terhadap PAD pada periode tahun 2010-2013.

(7) Membuat kesimpulan.

\section{HASIL DAN PEMBAHASAN}

DPPAD Provinsi Jawa Tengah mempunyai tugas untuk mengelola keuangan daerah. Pengelolaan keuangan daerah yang baik akan berdampak pada peningkatan PAD dan meningkatnya usaha-usaha pembangunan. Penerimaan PAD provinsi Jawa Tengah tidak selalu mengalami kenaikan setiap tahunnya. Data realisasi penerimaan PAD provinsi Jawa Tengah selama tahun 2010 - 2014 dapat dilihat pada Tabel 1. 
Tabel 1. Penerimaan PAD Provinsi Jawa Tengah (Dalam Rupiah)

\begin{tabular}{ll}
\hline Tahun & Jumlah \\
\hline 2010 & 4.417 .869 .229 .53 \\
2011 & 5.088 .713 .212 .530 \\
2012 & 6.044 .043 .900 .46 \\
2013 & $7 \cdot 590.460 .572 .08$ \\
2014 & 9.916 .315 .624 .21 \\
\hline
\end{tabular}

\section{Efektifitas Pajak Daerah}

Pajak daerah merupakan sumber penerimaan PAD yang sangat penting dalam pembiayaan pembangunan daerah. Besarkecilnya pajak daerah mempengaruhi kapasitas anggaran dalam membiayai pengeluaran, baik untuk pembangunan maupun anggaran rutin.

Sumber : DPPAD Provinsi Jawa Tengah

Table 2. Penerimaan Pajak Daerah Provinsi Jawa Tengah (Dalam Persentase)

\begin{tabular}{llll}
\hline Tahun & Target & Realisasi & \% perkembangan realisasi \\
\hline 2010 & $3,076,000,000,000$ & $3,893,699,996,503$ & - \\
2011 & $4,263,000,000,000$ & $4,599,046,986,897$ & 18,12 \\
2012 & 1.018 .500 .000 .000 & $5,590,597,156,499$ & 21,56 \\
2013 & $5,273,190,000,000$ & $6,716,170,095,203$ & 20,16 \\
2014 & $5,870,500,000,000$ & $8,213,117,977,940$ & 22,29 \\
Rata - rata & & & 14,42 \\
\hline
\end{tabular}

Sumber : DPPAD Provinsi Jawa Tengah

Table 3. Efektifitas Penerimaan Pajak Daerah Provinsi Jawa Tengah (Dalam Rupiah)

$\begin{array}{lll}\text { Tahun Target } & \text { Perkembangan } \\ & \text { Realisasi } & \text { Efektifitas }\end{array} \quad$ Keterangan

\begin{tabular}{llllll}
\hline 2010 & $3,076,000,000,000$ & $3,893,699,996,503$ & - & 1,27 & Sangat Efektif \\
2011 & $4,263,000,000,000$ & $4,599,046,986,897$ & 18,12 & 1,08 & Sangat Efektif \\
2012 & 5.018 .500 .000 .000 & $5,590,597,156,499$ & 21,56 & 1.11 & Sangat Efektif \\
2013 & $5,273,190,000,000$ & $6,716,170,095,203$ & 20,16 & 1,27 & Sangat Efektif \\
2014 & $5,870,500,000,000$ & $8,213,117,977,940$ & 22,29 & 1,40 & Sangat Efektif \\
\multicolumn{2}{l}{ Rata - rata } & & 14,42 & & \\
\hline
\end{tabular}

Sumber : DPPAD Provinsi Jawa Tengah 
Berdasarkan Tabel.2, perkembangan penerimaan pajak daerah selama periode tahun 2010 - 2014 dari realisasi sebesar 3,893,699,996,503 - 8,213,117,977,940 yaitu sebesar 110,93\% . Perkembangan terbesar dari total penerimaan pajak daerah provinsi Jawa Tengah dalam kurun waktu 2010 - 2014 terjadi pada tahun 2014 yaitu sebesar 22,29\% dan terendah pada tahun 2011 yaitu sebesar 18,12\%. Rata-rata perkembangan penerimaan pajak daerah dalam kurun waktu 5 tahun sebesar 14,42\%. Penerimaan pajak daerah provinsi Jawa Tengah pada tahun 2010 - 2014 terus meningkat dengan prosentase yang cukup tinggi. Hal ini disebabkan karena jenis pajak daerah tidak dapat dikembangkan dengan mudah dan sudah banyaknya wajib pajak. Berdasarkan uraian di atas selama kurun waktu 2010 sampai dengan tahun 2014 rata-rata tingkat efektivitas pajak daerah sebesar 14,42\%. Hasil perhitungan ini diperoleh dengan cara membagi jumlah rasio efektivitas pajak daerah tahun 2010 sampai dengan 2014. Dengan demikian berdasarkan tabel 4.3 efektivitas pajak daerah tergolong sangat efektif. Jumlah target pajak daerah setiap tahunnya terus meningkat begitu pula dengan jumlah realisasi pajak daerah yang mampu merealisasikannya dengan melebihi target yang telah ditetapkan. Pajak daerah dikategorikan efisien, hal ini dikarenakan rasio efisiensinya kurang dari atau tidak lebih dari 5\%.

\section{Efektivitas Penerimaan Retribusi Daerah}

Efektivitas merupakan hubungan antara output dengan tujuan yaitu semakin besar kontribusi ouput terhadap pencapaian tujuan, maka semakin efektif organisasi, program, atau kegiatan. Untuk mengukur tingkat efektivitas penerimaan pajak daerah atau retribusi daerah untukmasing-masing sektor dengan membandingkan antara realisasi penerimaan pajak daerah maupun retribusi daerah dengan sasaran atau target penerimaan pajak daerah dan retribusi daerah yang direncanakan. Semakin tinggi tingkat efektivitas berarti semakin efektif kinerjanya.

Table 4. Penerimaan Retribusi Daerah Provinsi Jawa Tengah (Dalam Rupiah)

\begin{tabular}{lllll}
\hline Tahun & Target & Realisasi & & $\begin{array}{c}\text { Perkembangan } \\
\text { Realisasi (\%) }\end{array}$ \\
\hline 2010 & 87.178 .314 .000 & $127.685 .944,78$ & - & \\
2011 & 84.412 .071 .932 & $63.711 .503,53$ & $-0,50$ & \\
2012 & 96.899 .998 .000 & $68.250 .727,46$ & 0,07 & \\
2013 & 10.473 .090 .600 & $1.020 .335 .264,93$ & 13,95 & \\
2014 & $69.911 .722,66$ & $79.475 .022,66$ & $-0,92$ & \\
Rata - rata & & & 12,60 & \\
\hline
\end{tabular}

Sumber : DPPAD Provinsi Jawa Tengah 
Tabel 5. Efektifitas Penerimaan Retribusi Daerah Provinsi Jawa Tengah (Dalam Persentase)

\begin{tabular}{|c|c|c|c|c|c|}
\hline Tahun & Target & Realisasi & $\begin{array}{l}\text { Perkembangan } \\
\text { Realisasi (\%) }\end{array}$ & Efektivitas & Keterangan \\
\hline \multirow{2}{*}{2010} & \multirow{2}{*}{$87.178 .314 .000,00$} & \multirow{2}{*}{$127.685 .944 .780,00$} & & \multirow{2}{*}{1,46} & Sangat \\
\hline & & & & & Efektif \\
\hline \multirow{2}{*}{2011} & \multirow{2}{*}{$84.412 .071 .932,00$} & \multirow{2}{*}{63.711 .503 .530} & \multirow{2}{*}{$-0,50$} & \multirow{2}{*}{0,75} & Sangat \\
\hline & & & & & Efektif \\
\hline \multirow{2}{*}{2012} & \multirow{2}{*}{ 96.899.998.00o,oo } & \multirow{2}{*}{68.250 .727 .460} & \multirow{2}{*}{0,07} & \multirow{2}{*}{0,70} & Sangat \\
\hline & & & & & Efektif \\
\hline \multirow{2}{*}{2013} & \multirow{2}{*}{$10.473 .090 .600,00$} & \multirow{2}{*}{1.020 .335 .264 .930} & \multirow{2}{*}{13,95} & \multirow[b]{2}{*}{$97,4^{2}$} & Sangat \\
\hline & & & & & Efektif \\
\hline \multirow{2}{*}{2014} & \multirow{2}{*}{$69.911 .722 .600,00$} & \multirow{2}{*}{79.475 .022 .650} & \multirow{2}{*}{$-0,92$} & \multirow{2}{*}{1,14} & Sangat \\
\hline & & & & & Efektif \\
\hline \multicolumn{2}{|c|}{ Rata - rata } & & 12,60 & & \\
\hline
\end{tabular}

Sumber : DPPAD Provinsi Jawa Tengah

Berdasarkan uraian di atas menganai efektivitas retribusi daerah selama kurun waktu 2010 sampai dengan tahun 2014 pada tabel 5 rata-rata tingkat efektivitas sebesar 12,60\% yang termasuk kategori sangat efektif. Dilihat pada tabel 5 tingkat efektivitas retribusi daerah tertinggi terjadi pada tahun 2013 sebesar 97,42\% dan tingkat efektivitas terendah ada pada tahun 2012 sebesar $0,70 \%$. Secara umum rasio efektivitasnya naik turun setiap tahunnya, jika dilihat dari jumlah target retribusi daerah terjadi penurunan dimana pada tahun 2012 jumlah targetnya lebih besar dibandingkan tahun 2014 walupun terjadi kenaikan dan penurunan jumlah target retribusi daerah namun dapat direalisasikan melebihi target yang sudah ditetapkan.

\section{Efisiensi Pajak Daerah}

Efisiensi merupakan perbandingan antara output dengan input. Untuk mengukur tingkat efisiensi penerimaan masing-masing jenis pajak daerah dengan membandingkan antara biaya pemungutan pajak daerah maupun retribusi daerah yang dikeluarkan dengan realisasi penerimaan pajak daerah maupun retribusi daerah. Semakin kecil tingkat efisien berarti semakin baik kinerjanya. Yang dimaksud output yaitu biaya yang dikeluarkan dalam upaya pemungutan pajak daerah dan retribusi daerah.

$$
\text { Dalam Tabel } 5 \text { terlihat bahwa }
$$
selama kurun waktu 5 tahun, tingkat efisiensi rata - rata penerimaan pajak daerah sebesar o,o76. Berdasarkan kriteria efisiensi yang digunakan, hal itu menunjukkan bahwa DPPAD (Badan Pengelola Penerimaan Pendapatan Asli Daerah) provinsi Jawa Tengah telah melaksanakan kegiatan pengelolaan dengan sangat efisien, hal itu artinya manfaat yang didapatkan lebi 
besar daripada jumlah biaya yang Untuk mengetahui besar kontribusi pajak dikeluarkan. daerah terhadap PAD (Pendapatan Asli

Kontribusi Pajak Daerah Daerah) yaitu dengan membandingkan realisasi pajak daerah dengan realisasi sumber kontribusi dana terhadap PAD. PAD (Pendapatan Asli Daerah).

Table 6. Efisiensi Pajak Daerah (Dalam Rupiah)

$\begin{array}{llll}\text { Tahun Realisasi Pajak daerah } & \begin{array}{l}\text { Biaya Pemungutan } \\ \text { Pajak Daerah }\end{array}\end{array}$ Efisiensi Keterangan

\begin{tabular}{lllll}
\hline 2010 & $3,893,699,996,503$ & $3,375,393,000$ & 0,087 & Sangat Efisien \\
2011 & $4,599,046,986,897$ & $3,750,000,000$ & 0,082 & Sangat Efisien \\
2012 & $5,590,597,156,499$ & $3,560,170,000$ & 0,064 & Sangat Efisien \\
2013 & $6,716,170,095,203$ & $3,467,390,000$ & 0,052 & Sangat Efisien \\
2014 & $8,213,117,977,940$ & 3.350 .509 .000 & 0,045 & Sangat Efisien \\
Rata-rata & & & 1,328 & \\
\hline
\end{tabular}

Sumber : DPPAD Provinsi Jawa Tengah

Table 7. Kontribusi Pajak Daerah terhadap PAD (Dalam Persentase)

\begin{tabular}{llll}
\hline Tahun & Realisasi Pajak Daerah & \multicolumn{1}{c}{ PAD } & \% Konstribusi Pajak Daerah terhadap \\
& & & \multicolumn{1}{c}{ PAD } \\
\hline 2010 & 3.893 .699 .997 & 4.417 .869 .260 & 0,881352473 \\
2011 & 4.599 .046 .987 & 5.088 .713 .213 & 0,903774057 \\
2012 & 5.590 .597 .157 & $6.044 .043 .900,46$ & 0,924976266 \\
2013 & $6.716 .170 .095,20$ & 7.590 .460 .572 & 0,884817203 \\
2014 & $8.213 .117 .977,93$ & $9.916 .315 .624,21$ & 0,828242897 \\
Rata - rata & & & 4,423162896 \\
\hline
\end{tabular}

Sumber : DPPAD Provinsi Jawa Tengah

Berdasarkan Tabel 6, rata-rata kontribusi pajak daerah terhadap PAD selama kurun waktu 5 tahun sebesar 4,42\%. Besarnya kontribusi menunjukkan bahwa penerimaan pajak daerah memiliki peran besar dalam penerimaan PAD setiap tahunnya dibandingkan dengan sumber penerimaan PAD yang lain, sehingga perlu dikelola dengan 
baik guna menunjang PAD di provinsi Jawa Tengah. Selanjutnya berdasarkan Tabel 8, ratarata kontribusi retribusi daerah terhadap PAD selama kurun waktu 5 tahun sebesar o,0699\%. Besarnya kontribusi menunjukkan penerimaan pajak daerah memiliki peran besar dalam penerimaan PAD setiap tahunnya dibandingkan dengan sumber penerimaan PAD yang lain. Sehingga perlu juga dikelola dengan baik guna menunjang PAD Provinsi Jawa Tengah.

Table 8. Konstribusi Retribusi Daerah terhadap PAD (Dalam Persentase)

Tahun Realisasi Retribusi Daerah PAD Konstribusi Retribusi Daerah terhadap PAD

\begin{tabular}{llll}
\hline 2010 & $127.685 .944,78$ & 4.417 .869 .230 & 0,0289 \\
2011 & $63.711 .503,53$ & 5.088 .713 .213 & 0,0125 \\
2012 & $68.250 .727,46$ & $6.044 .043 .900,46$ & 0,0113 \\
2013 & $69.911 .722,66$ & $7.590 .460 .572,08$ & 0,0092 \\
2014 & $79.475 .022,66$ & 9.916 .315 .624 & 0,0080 \\
rata - rata & & & 0,0699 \\
\hline
\end{tabular}

Sumber : DPPAD Provinsi Jawa Tengah

\section{SIMPULAN}

Berdasarkan hasil analisa dan pembahasan pada bab sebelumnya, maka dapat ditarik kesimpulan bahwa pajak daerah selama periode tahun 2010 - 2014 dari realisasi sebesar $3,893,699,996,503$ - 8,213,117,977,940 yaitu sebesar $110,93 \%$.

Berdasarkan uraian selama kurun waktu 2010 sampai dengan tahun 2014 rata-rata tingkat efektivitas pajak daerah sebesar $14,42 \%$. Efektifias retribusi daerah selama kurun waktu 2010 sampai dengan tahun 2014 pada tabel 5 rata-rata tingkat efektivitas sebesar $12,60 \%$.

Berdasarkan kriteria efisiensi yang digunakan, menunjukkan bahwa DPPAD provinsi Jawa Tengah telah melaksanakan kegiatan pengelolaan dengan sangat efisien, berarti manfaat yang didapatkan lebih besar daripada jumlah biaya yang dikeluarkan selama kurun waktu 5 tahun, tingkat efisiensi rata - rata penerimaan pajak daerah sebesar o,o76. Sedangkan rata-rata kontribusi pajak daerah terhadap PAD selama kurun waktu 5 tahun sebesar $4,42 \%$.

\section{DAFTAR PUSTAKA}

Arikunto Suharsimi. 2010. Prosedur Penelitian. Yogyakarta. Rineka Cipta.

Anggraeni, Dian. 2010. Analisis Pengaruh Penerimaan Pajak Daerah dan Retribusi Daerah terhadap Peningkatan Pendapatan Asli Daerah (Studi empiris pada propinsi Bengkulu.

Akbar, Bahrullah. 2010. Fungsi Manajemen Keuangan Daerah. www.osun.org

Ayuningtyas, Arniyanti. 2008. Analisis Pengaruh Pendapatan Pajak Daerah, Retribusi Daerah Terhadap Anggaran Belanja Daerah (Studi kasus pada seluruh kabupaten di provinsi Jawa Tengah. Skripsi pada FEIS UIN Jakarta

Dinas Pendapatan dan Pengelolaan Aset Daerah (DPPAD) Provinsi Jawa Tengah 
Halim Abdul, (2004). Akuntansi Sektor pubik, Akuntansi Keuangan Daerah. PS Salemba Empat : Jakarta.

Kaho, Josef Riwu, 2005, Prospek Otonomi Daerah di Negara Republik Indonesia. Fak. Sospol - UGM, Yogyakarta

Mardiasmo. 2009. Perpajakan Edisi Revisi 2009. Penerbit Andi : Yogyakarta.

Mayasari, Dian. 2009. Konstribusi Penerimaan Pajak Daerah terhadap Pendapatan Asli Daerah (Analisis Terhadap Kabupaten dan Kota di Jawa Timur). Skripsi pada FE UMM

Mardiasmo. 2005. Akuntansi Sektor Publik. Yogyakarta: Andi Offset.

P. Marihot Siahaan, 2006, Pajak Daerah dan Retribusi Daerah. Penerbit UII PRESS : Yogyakarta.

Republik Indonesia. Pokok - Pokok Pengaturan Undang undang Pajak Daerah dan Retribusi Daerah.

Republik Indonesia. Undang - undang No. 32 Tahun 2004 Tentang Pemerintah Daerah

Republik Indonesia. Undang - undang No. 33 Tahun 2004 Tentang Perimbangan Keuangan Antara Pemerintah Pusat dan Pemerintah Daerah
Republik Indonesia. Undang - undang No. 28 Tahun 2007 Tentang Ketentuan Umum dan Tata Cara Perpajakan

Republik Indonesia. Undang - undang No. 28 Tahun 2009 Tentang Pajak Daerah dan Retribusi Daerah

Riduansyah, Mohammad. 2003. Konstribusi Pajak Daerah dan Retribusi Daerah Terhadap Pendapatan Asli Daerah (PAD) dan Anggaran Pendapatan dan Belanja Daerah (APBD) Guna Mendukung Pelaksanaan Otonomi Daerah (Studi Kasus Pemerintah Daerah Kota Bogor). Makara, Sosial Humaniora. Vol. 7, No. 2

Tim Redaksi Nuansa Aulia. 2009. Undang - undang Tentang Pajak Daerah dan Retribusi Daerah. Nuansa Aulia : Bandung

Tim Jurnal Otonomi Daerah. 20o8. Dampak Desentralisasi Fiskal Terhadap Pembangunan Daerah. Vol. VIII. No.4. Hal. 28 - 30

Yani , Ahmad. 2003. Hubungan Keuangan Antara Pemerintah Pusat dan Pemerintah Daerah di Indonesia, PT. Raja Grafindo Persada.

Waluyo. 2005. Perpajakan Indonesia. Jakarta: Salemba Empat. 
